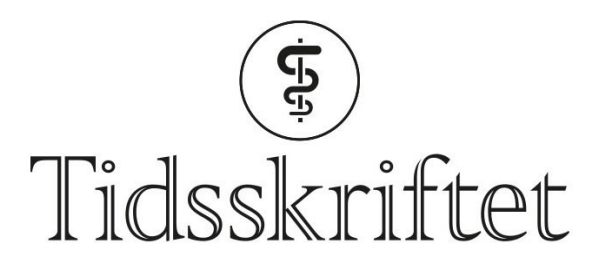

DEN NORSKE LEGEFORENING

\title{
Bruk av iPad økte oppslutningen om tarmkreftscreening
}

FRA ANDRE TIDSSKRIFTER

ØYVIND STOPLE SIVERTSEN

Tidsskriftet

Bruk av iPad som beslutningsstøtte førte til dobling av andelen som gjennomførte tarmkreftscreening.

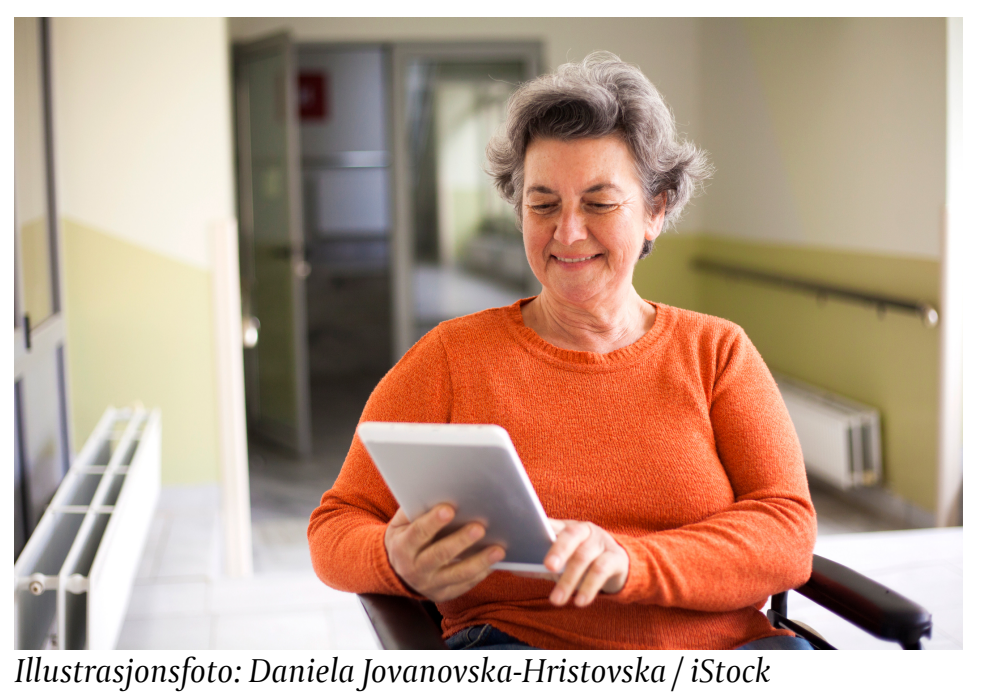

Mer enn en tredel av pasientene som faller inn under inklusjonskriteriene for tarmkreftscreening i USA, avstår fra undersøkelsen. Dette gjelder særlig personer med lav inntekt og de med redusert evne til å motta, forstå og bearbeide helseinformasjon.

En studie som nylig er publisert i Annals of Internal Medicine, viser at flere lar seg undersøke dersom en applikasjon på iPad brukes tidlig i prosessen (1).

I studien ble 450 pasienter over 50 år under en konsultasjon i primærhelsetjenesten randomisert til enten å bruke en applikasjon på iPad eller snakke videre med sin lege. Over halvparten av pasientene ble ansett å ha lav inntekt og 37 \% lav helsekyndighet, definert som redusert evne til å motta, forstå og bearbeide helseinformasjon. iPad-gruppen fikk informasjon om tarmkreft og ulike screeningmuligheter og kunne selv velge hvilken screeningmetode de ville gjennom. Deretter ble screeningen bestilt. I etterkant fikk de automatisk genererte tekstmeldinger om tidspunkt for testen. Etter 24 uker hadde $30 \% \mathrm{i}$ iPad-gruppen gjennomført screening, mot $15 \%$ i kontrollgruppen (oddsratio 2,5; 95 \% KI $1,6-4,0)$. 
- Denne studien er interessant fordi den tar i bruk moderne teknologi som beslutningsstøtte i valg av screeningmetode for tarmkreft, sier Øyvind Holme, som er leder av tarmscreeningseksjonen ved Kreftregisteret.

- Kun informasjon er sannsynligvis ikke tilstrekkelig, men må kombineres med mulighet for å bestille time til screening, slik deltagerne kunne gjøre i denne studien, sier han.

- En svakhet ved studien er at innholdet i beslutningsstøtten ikke er gjort tilgjengelig for leseren. Det er derfor vanskelig å vurdere om opplegget egner seg for norske forhold, sier Holme.

\section{LITTERATUR:}

1. Miller DP, Denizard-Thompson N, Weaver KE et al. Effect of a digital health intervention on receipt of colorectal cancer screening in vulnerable patients. Ann Intern Med 2018; 168: 550 - 7.

[PubMed][CrossRef]

Publisert:3. september 2018. Tidsskr Nor Legeforen. DOI: 10.4045/tidsskr.18.0507

(C) Tidsskrift for Den norske legeforening 2020. Lastet ned fra tidsskriftet.no 